\title{
HOUSING SUBSIDIES AND HOMELESSNESS: A SIMPLE IDEA
}

\author{
Brendan O'Flaherty* \\ Department of Economics, Columbia University
}

\section{SUMMARY}

Reducing homelessness is an indisputable social good, and housing subsidies offer one way to do so. However, subsidies come in many different varieties and are intricately bound up with economic and social policies. This paper, written by one of North America's leading urban economists, cuts through the tangle and argues that the simplest approach is the best. The ideal way to deter people from harmful acts is to reward them for abstaining. Thus, to combat homelessness, governments should offer housing allowances to people for every night they are not homeless. This optimal homelessness-reducing home allowance (OHRHA) is open to adjustment to suit individual circumstances and the effects of homelessness on different demographics. It is meant to reduce homelessness by aligning individual and societal incentives, forcing people to bear the consequences or realize the benefits that their actions impose on others. The author explores methods for financing OHRHA, examines means for tailoring it to meet the diverse needs of the homeless and discusses the policy's effect on urban housing markets, all while comparing and contrasting the proposal to existing homelessness-reduction measures in Alberta, Canada and the US.

\footnotetext{
* I have benefited from helpful comments and discussions by Ron Kneebone, Marion Steele and an anonymous referee.
} 


\section{INTRODUCTION}

Homelessness can be reduced only if people who would otherwise be homeless somehow find or maintain a conventional place to live. That happens only if they have more resources, or if housing becomes cheaper for them. Housing subsidies are one way that housing can be made cheaper for some people who might otherwise be homeless. Housing subsidies come in many different varieties. In this paper, I look at how they might be used to reduce homelessness in Calgary. Although I refer in the paper specifically to Calgary and to the tax and social assistance programs in place in Alberta, there is nothing in what I say that cannot be applied equally well to other Canadian cities.

Housing subsidies are not the only possible strategy for reducing homelessness. For instance, many interventions have tried to raise the resources that homeless people have by improving their psychiatric functioning, increasing their work skills or qualifying them for government benefits. Rosenheck finds that these service interventions often succeed in their immediate objectives, but unless they are tied to housing subsidies generally, they do not make a dent in homelessness. ${ }^{l}$ Other strategies for making housing cheaper operate by changing how housing markets operate, or increase resources by changing how labour markets operate. Raphael, for instance, finds that moderately reducing the stringency of local land use regulations would make a substantial dent in US homelessness. ${ }^{2}$ Both service interventions and market-wide policies are beyond the scope of this paper.

My main point is that for reducing homelessness, the optimal housing subsidy is extremely simple: a lump-sum reward for being housed. This subsidy might depend on the characteristics of the person receiving it, since some varieties of homelessness may be more expensive than others, but the allowance should not depend on rent, income, residence in a particular building or anything else. If you want people to be housed rather than homeless, reward them for being housed.

I also show some good ways to approach other problems, like volatility and poorly located housing.

To begin, though, I need some basic groundwork.

\section{WHAT ARE HOUSING SUBSIDIES?}

I'll use a broad definition. Housing subsidies (for me) are government payments to providers or residents that are intended to lower the costs of certain types of conventional housing for particular households. I confess that this is mushy and contains references to intentions that are not observable, but to avoid arguments I want to interpret it liberally.

1 Rosenheck, Robert, (2010), "Service models and mental health problems: Cost-effectiveness and policy relevance," pp. 17-36 in Ingrid Ellen and Brendan O'Flaherty, eds., How to House the Homeless. New York: Russell Sage.

2 Raphael, Steven, (2010), "Housing market regulation and homelessness," pp. 110-39 in Ingrid Ellen and Brendan O’Flaherty, eds., How to House the Homeless. New York: Russell Sage 
It's best to give examples. Included in my definition are programs that pay poor households or their landlords an amount of money toward their rent on a monthly basis, programs that subsidize the construction of housing that must be rented or sold to poor people and programs that pay a portion of mortgage costs. Excluded are homeless shelters (even those where residents pay some rent), hospitals and therapeutic communities.

\section{WHAT SHOULD THEY DO?}

In this paper, I will examine how to design these subsidies to reduce homelessness. Stating this goal precisely, however, is not trivial.

A major question is whether all nights of homelessness are equally bad. This question has several dimensions.

One dimension is personal. Should we consider a night of homelessness experienced by a 10 -year-old child to be equivalent to a night experienced by a severely mentally ill 40 -year-old man or a healthy 20-year-old woman?

Another dimension is temporal. Is the first day of a person's homeless spell as much of a problem as the hundredth day, or less of a problem? Are short homeless spells like colds that go away or like traffic accidents that, while short in duration, can radically alter a person's life for the worse?

The third dimension is structural. Is it worse to be homeless on the street or in a shelter, on the street in January or in July?

Most of these questions are empirical, and those that are not have large empirical components. But very little of the empirical work required to answer these questions has been done. In the absence of solid answers (or any answers at all) to these basic questions, I'll work on the presumption that all nights of homelessness are equally bad. However, I'll explore some of the implications of plausible differences in the harm caused by different nights of homelessness.

Because I'll be working on the presumption that all nights of homelessness are approximately equally bad, I want to use a fairly strict definition of what constitutes homelessness. As a first approximation, I mean literal homelessness - sleeping in a shelter or in a place not meant for human habitation. Enormous amounts of energy have been devoted to trying to divine a correct definition of homelessness without the assistance of empirical study. I will not devote any energy to this pursuit. This paper works with any internally consistent definition of homelessness. It works best with definitions that have empirical support. I return to this issue in a later section.

\section{THE BASIC ANSWER}

To deter people from doing something bad, you either punish them for doing it or reward them for not doing it. The punishment or reward should be proportional to the harm that the action causes. 
Hence people should either be punished for being homeless or rewarded for not being homeless. Punishing people for being homeless is cruel and ineffective. So people should be rewarded for not being homeless, proportional to the number of nights they are not homeless. That means a housing subsidy - you get money for being housed.

A housing allowance designed to eliminate excess homelessness is simple - it's a flat amount. It goes to everyone who is not homeless for every night he or she is not homeless. If everyone's homelessness is equally bad, then this amount is the same for everyone, but if some kinds of homelessness are worse than others, the allowance should be higher for people more likely to experience worse kinds of homelessness. For instance, if child homelessness is worse than adult homelessness because it has long-lasting developmental effects (we don't know whether it does or not), then households with children should get bigger housing subsidies. But nothing about the housing subsidy should be tied to current conditions or easily malleable past conditions - it should not depend on income or rent or whether you live in a building with the right type of management.

I label this program the optimal homelessness-reducing home allowance - OHRHA.

OHRHA is what economists call a Pigouvian subsidy. A Pigouvian tax or subsidy aligns an individual's incentives with those of the rest of society by making her bear all the costs or realize all the benefits that her actions impose on other people. For instance, a Pigouvian tax on industrial emissions charges polluters an amount equal to the damage their emissions cause.

You can find a rigorous derivation of OHRHA as the solution to a stochastic dynamic optimization problem in O'Flaherty. ${ }^{3}$

OHRHA won't necessarily eliminate homelessness, any more than a Pigouvian tax on industrial emissions will necessarily eliminate emissions, but it will reduce homelessness. Whether or not it eliminates homelessness depends on how bad people in Calgary think homelessness is and how much they are willing to pay to prevent people from being homeless; if this amount is very high, then OHRHA will be very large and make homelessness very small or zero. Drunken driving deaths are very bad and they are punished severely, but they still occur, so zero homelessness is unlikely.

If someone really wants to spend all his money on gourmet food and live in the Calgary bus terminal, and his living in the bus terminal doesn't harm other people much, even vicariously, there is little reason he should not do so. The overwhelming majority of homeless people today are not like this, and we should concentrate on reducing current, actual homelessness before arguing over systems to deal with eccentric gourmets.

\section{FINANCING OHRHA}

How should OHRHA be financed? OHRHA is a Pigouvian subsidy and should be financed like any other Pigouvian subsidy - by lump sum or land value taxes. The idea is to change one particular behaviour, and lump-sum taxes change no behaviour in a relevant way. 3 O'Flaherty, Brendan, (2011a), Individual Homelessness: Entries, Exits, and Policy. Working paper, Columbia
University Economics Department. 
To see this, think about a more pleasant problem. What should be done about the revenue generated by a Pigouvian tax - say, a fine for double parking? The classical answer is pretty intuitive. Just give it away, like the Alaska demo-grants (Alaska distributes a portion of mineral revenue to every citizen), but not in a way that rewards people for doing something socially harmful, or use it to reduce taxes that are causing people to do socially harmful things. For an example, see Parry and Small for an insightful analysis of optimal gasoline and vehicle miles traveled (VMT) taxes in the US and Britain. ${ }^{4}$

For Pigouvian subsidies, the same logic holds - raise the revenue in a way that does not distort other decisions. Lump-sum taxes are one obvious solution, but Henry George proposed a fairer and cleverer alternative over a century ago: a land value tax. ${ }^{5}$ A standard property tax, like the one Calgary has, taxes the (assessed) value of both improvements and land. A land value tax falls only on land and exempts improvements.

To economists, the appeal of the land tax is that it does not distort decisions. The improvement part of the current property tax discourages people from building better houses and stores, but nothing can change the amount of land in Calgary, or where it is located. To most noneconomists (and some economists too), the appeal is fairness. Most other general purpose taxes make people pay for what they produce for society (the value of the output you produce, for the income tax, or the house you build, for the improvement part of the property tax), but the land value tax makes you pay for what you get, not what you give. Land is valuable not because of any actions its owner takes, but because of the public services it enjoys and because of its propinquity to the activities of other people like stores, workplaces and recreational outlets.

Both reasons argue for financing OHRHA through a land value tax. Land taxes won't distort other decisions and so economists will be happy. Moreover, the benefits of OHRHA - regular payments and the external benefits of fewer homeless people - will make Calgary more attractive, and so rents and land prices will be bid up. The people who ultimately benefit landowners - will be the people who pay. That's fair.

The fairest land value tax to finance OHRHA is on the value of the increment to land value that OHRHA causes. Because OHRHA corrects a market failure, the total increment to land value in Calgary due to OHRHA will exceed the cost of OHRHA. Hence a tax proportional to land value increments will raise the full cost of OHRHA, and still leave landowners better off than before OHRHA.

Calculating the exact land value increments that OHRHA causes is hard, since OHRHA is only one small influence on Calgary land values, but estimates can be made. The OHRHA land tax would probably be greatest on large and valuable properties near places where homeless people are often seen now, and on land that could house large numbers of OHRHA-eligible people.

4 Parry, Ian W.H., and Kenneth Small, (2005), "Does Britain or the United States have the right gasoline tax?" American Economic Review 95 (4): 1276-89.

5 George, Henry, 1879 (2001), Progress and Poverty: An Inquiry in the Cause of Industrial Depression and of Increase in Want with Increase in Wealth... The Remedy. New York: Robert Schalkenbach Foundation 
If neither land value nor lump-sum taxes are available to finance OHRHA (and similarly all other Pigouvian tax options like gasoline and VMT taxes are off the table too), then we are in the realm of uncomfortable compromises that economists call "second best." Full OHRHA will not be optimal. Instead we must sail skillfully between the Scylla of distortions to the behaviour of recipients from limiting eligibility and the Charybdis of distortions to the behaviour of taxpayers from taxing behaviour under their control. Skillful navigation requires good local maps, not something somebody sitting a few thousand miles away can compile without estimating many of the relevant elasticities. I can provide only generalities.

On the Charybdis of taxation side, the general principles of skillful navigation are well known and can be found in any public finance textbook. Raising money for OHRHA is no different from raising money for a fire truck or a police officer. If Calgary already has a pretty good tax system, then the marginal deadweight loss from raising any tax is just about the same, and so all taxes should be raised a little. If not, then the least distorting tax should be raised (as long as it's still the least distorting).

On the Scylla of eligibility, much less is known. The social benefit of the subsidy is small when it makes little difference in the expected discount factor for the time at which a person becomes homeless (which is zero if the probability is zero that the person will become homeless). We can probably identify small changes with small magnitudes in the absence of the subsidy. Thus, if doing so were legal, restricting eligibility to men would probably be a good idea in an inefficient tax world, since men are much more likely to become homeless in Calgary and gender is hard to change. In general, future homelessness is hard to predict, even using characteristics that are highly mutable, ${ }^{6}$ and income appears not to be a very good predictor. ${ }^{7}$ If OHRHA had to be financed in a very bad tax system, my guess is that eligibility would best be restricted to people living in certain classes of inexpensive housing, to individuals in households with three or more adults and to individuals with histories of certain kinds of mental illness.

But land taxes are a much better idea. And land taxes are not impractical. The largest construction project in world history, the urbanization of China, is now being financed by implicit land taxes. There's nothing wrong with doing something right.

\section{HOUSEHOLD ISSUES}

A key question about OHRHA that I fudged in the last sections is what unit gets it - the household or the individual. If households were immutable, this would not be an issue since they would live together and be homeless together. But households are not immutable. They form and break up frequently, add and shed members and most importantly, they do these things in response to economic incentives, according to abundant evidence.

6 Shinn, Marybeth et al. (1998), "Predictors of homelessness among families in New York City: From shelter request to stability," American Journal of Public Health 88(11): 1651-57.

7 Sullivan, James X., Lesley J. Turner, and Sheldon Danziger, (2008), “The relationship between income and material hardship," Journal of Policy Analysis and Management 27(1): 63-81. 
Let's concentrate on adults first, since children present special issues. For the most part, the external cost of adult homelessness is proportional to the number of adults who become homeless. So the OHRHA should be proportional to the number of adults in the household. Essentially, individual adults rather than households should receive the allowance, even if they should happen to be living together at the moment. This is a major departure from US practices, which usually penalize adults who share housing with other adults.

This does not mean that all adults should receive the same allowance. If, for instance, the general public finds pregnant women's homelessness or veterans' homelessness more appalling than other varieties of adult homelessness, or that it has some other greater social cost, then allowances should be greater for pregnant women or for veterans. But the allowance should not depend on whom the person is living with at the moment.

Children are different from adults. They don't enter shelters on their own, the social costs of their homelessness are different from those of adults and they don't have legal standing to handle money. So the OHRHA for children should be different from the OHRHA for adults, and it should go to the adults with whom the children are living. Possibly the amount should differ with the child's age (though I'm aware of no current research that would justify or guide such differentiation). The amount per child might also decrease with the number of children in a household, if the primary external cost of homelessness is shelter space and a group of children can be sheltered more cheaply per child than a lone child. But if the primary cost is developmental loss, then the amount per child should be independent of the number of children.

\section{WHAT'S DIFFERENT ABOUT OHRHA?}

In this section, I'll compare OHRHA with several existing programs that bear a superficial resemblance.

\section{Alberta Works}

In some ways, OHRHA looks like the core shelter benefit in the income support component of Alberta Works and many other provincial social assistance programs. Both give money for being housed and both end when the recipient becomes homeless. If the core shelter benefit were the same as OHRHA, I would be very happy because I would not have to persuade anyone to do anything differently. Alberta Works, however, has many goals, and keeping people from being homeless isn't even listed among them on the website. So OHRHA is really quite different from anything in Alberta Works, despite the superficial similarity.

Alberta Works, for instance, has asset restrictions. You have to spend down your assets before Alberta Works will give you money. OHRHA has no asset restrictions. In fact, one goal of OHRHA is to encourage people to accumulate and hold precautionary savings so that they don't become homeless.

Alberta Works also requires that recipients spend the entire amount of the benefit on rent and related expenses, and reduces the benefit if a recipient's rent is less than the maximum allowed. OHRHA does not punish people for living cheaply, as long as they're not homeless. 
Social housing tenants get smaller benefits than private housing tenants under Alberta Works; they would not under OHRHA. If Mr. Jones pays Mr. Smith to shovel his driveway, it may keep Mr. Smith from becoming homeless, but no one would propose reducing Mr. Smith's OHRHA or giving it to Mr. Jones on that account. Presumably Mr. Jones made the payment in order to get his driveway shoveled. Similarly the government set up social housing for reasons unrelated to homelessness - to make poor people healthier or eliminate slums, for instance. Social housing tenants are being paid for their contribution to the public good of carrying out the goals of social housing. If they are being paid too much for that, that is a problem with social housing, not with OHRHA. Columbia University should not be able to claim my OHRHA by saying that it is preventing me from being homeless and neither should social housing operators.

Provincial social assistance programs like Alberta Works have rules about many kinds of behaviour, because they care about many kinds of behaviour. You lose your benefits, for instance, if you quit an appropriate job for no good reason or stop attending your training program. OHRHA cares about only one behaviour and has only one rule.

Perhaps one could rationalize something like Alberta Works rules by arguing that the public is less upset by the homelessness of undeserving people than by the homelessness of deserving people. If so, then OHRHA would have to vary by many dimensions of deservingness, not just participation in work activities. Sloth, after all, is only one of seven deadly sins, and all of them can lead to external social costs.

Finally Alberta Works discourages sharing by reducing per-person payments in larger households. OHRHA would not.

OHRHA is much simpler than Alberta Works.

\section{Canadian housing allowances}

Four provinces (British Columbia, Manitoba, Saskatchewan and Quebec) have housing allowances, but they are also different from OHRHA. ${ }^{8}$ The big difference is that (with a minor exception) non-elderly adults unaccompanied by children - the demographic group most likely to become homeless in Calgary and elsewhere - are excluded from these programs. (In Manitoba and Quebec, elder status starts at age 55.) Over 80 percent of people in homeless households in Calgary in 2008 appear to be single adults. In Calgary, there were 4060 homeless people on the night of May 14, 2008. ${ }^{9}$ There were 190 families with children, ${ }^{10}$ but we don't know the size of these families. If the average family had four members, individuals in families with children would have accounted for 18.7 percent of homeless persons.

8 Steele, Marion, (2007), “Canadian housing allowances," pp. 61-85 in Peter Kemp, ed., Housing Allowances in Comparative Perspective. Bristol: The Policy Press.

9 City of Calgary, Community and Neighbourhood Services, Social Research Unit, 2008, Biennial Count of Homeless Persons in Calgary: 2008 May 14: Executive Summary. Accessed on March 22, 2011 at www.calgary.ca/docgallery/bu/cns/homelessness/2008_count_executive_summary.pdf.

10 ibid. 
The subsidies under these programs also depend both on actual rent and on actual household income. Land tax-funded OHRHA would depend on neither and OHRHA financed by an inefficient tax system might include a minor dependence on income. If the goal is to reduce homelessness, households paying higher rent should not get greater subsidies. Similarly, placing an added marginal tax on the earnings of low-income households seems like something program designers should strive assiduously to avoid.

Because they depend on actual rent, these programs also penalize adults who share housing, and thereby reduce the aggregate rent that they pay. Under OHRHA, two adults who decided to share an apartment would be able to keep for themselves all the rent that they save. Under these programs, they would have to share some of their savings with the provincial government in the form of reduced aggregate subsidies.

In one dimension, however, the provincial housing allowances are more like OHRHA than Alberta Works: none has an asset restriction that is binding in a substantial number of cases (BC had a low asset restriction until recently, but it has been raised).

\section{Section 8 in the U.S.}

Section 8 or Housing Choice vouchers are the US housing allowance - it was originally called Section 8 after the legislative provision in which it was first authorized, but was later officially renamed Housing Choice. I will say Section 8 because that is the more common term.

A household with a Section 8 voucher can use that voucher to rent any apartment whose landlord will rent it to them, provided it meets certain physical standards and has a rent that is "reasonable" compared with other apartments in the private market. To calculate the subsidy, the apartment's rent was compared with the fair market rent (FMR) for the household's size and composition. The FMR is calculated by the federal government to approximate the 40th percentile of the rent distribution for recent movers in each metropolitan area. If the rent does not exceed the FMR, the household pays 30 percent of its income as rent, and the voucher pays the rest of the rent. If the rent exceeds the FMR, the voucher pays the difference between the FMR and 30 percent of the tenant's income, and the tenant pays the rest. But the tenant cannot pay more than 40 percent of household income in rent. The Alberta rent supplement program resembles Section 8, although it sometimes allows direct payments to tenants instead of landlords.

Section 8 vouchers on average provide a subsidy several times as large as any of the housing allowances the Canadian provinces use, and more generous per recipient household than the housing allowances most other countries use (except Britain). For a detailed comparison, see Steele. $^{11}$

As in Calgary, the majority of point-in-time (PIT) homeless people are adults unaccompanied by children (63 percent in the 2009 Annual Homeless Assessment Report). ${ }^{12}$ Section 8 serves very few non-elderly single adults, although they are eligible. The virtual exclusion is de facto rather than de jure.

\footnotetext{
11 Steele, Marion, (2001), "Housing allowances in the US under section 8 and in other countries: A Canadian perspective," Urban Studies 38 (1): 81-103.

12 US Department of Housing and Urban Development, Office of Community Planning and Development, (2010), The 2009 Annual Homeless Assessment Report. Accessed on March 22, 2011 at www.hudhre.info/documents/5thHomelessAssessmentReport.pdf.
} 
Thus, except for the size and the way in which non-elderly single adults are excluded, Section 8 differs from OHRHA in all the ways that the Canadian housing allowances do. There is one huge additional difference - Section 8 is not an entitlement, and so there is a queue of eligible households waiting to get vouchers. No economists have been able to advance sound programmatic reasons for why Section 8 should operate this way. For other possible reasons, see O'Flaherty. ${ }^{13}$

\section{HOUSING FIRST AND SIMILAR PROGRAMS}

OHRHA is not necessarily a substitute for other programs for reducing homelessness, like Housing First (HF). HF targets long-term street dwellers and individuals with severe mental illness, and moves them immediately into subsidized, low-demand apartments. Relative to standard therapies, especially high-demand therapies, HF is much more successful at keeping its target population housed, and no worse in indicators of substance abuse and mental illness. ${ }^{14,15}$ The effect of treatment on the treated is quite good.

No studies have shown whether HF reduces the actual volume of homelessness, because HF alters incentives and the effect of treatment on the untreated is unknown. Casual evidence suggests that when HF is a surprise, street homeless population falls, but almost nothing is known about what happens when people expect HF to be operating and no rigorous studies have been done. In the long run, it is possible that the promise of a subsidized, low-demand apartment might encourage people to remain homeless longer, but we don't know.

OHRHA would allow HF to operate better for several reasons. First, HF operators now expend great effort rounding up rationed subsidies for the apartments they use; OHRHA would reduce this bureaucratic burden considerably. Second, OHRHA would reduce the number of people becoming chronically homeless. Finally, OHRHA would change the mix of chronically homeless people. There would be fewer, if any, queue-jumpers (since there would be no queue to jump) and more severely troubled individuals - the people whom HF is designed to help.

Many of the people who are homeless today have severe physical, psychological and occupational problems. OHRHA will do little to make those problems go away. They will still need help.

\section{WHO'S HOMELESS?}

The only people who don't receive a housing allowance under OHRHA are people who are homeless. That means OHRHA cannot be like the British housing allowance, which is used to fund shelters. OHRHA is not insurance; it's an incentive not to be homeless.

\footnotetext{
13 O'Flaherty, Brendan, (1999), "The form of US in-kind programs," Journal of Law, Economics, and Organization 15: 401-17.

14 Rosenheck (2010)

15 Tsemberis, Sam, Leyla Gulcur, and Maria Nakae, (2004), "Housing First, consumer choice, and harm reduction for homeless individuals with a dual diagnosis," American Journal of Public Health 94 (4): 651-56.
} 
Of course, that makes the definition of homelessness key to its administration. Notice that the incentives of advocates are quite different with OHRHA than they are when the only programs around are those that implicitly reward homelessness. Under those circumstances, advocates generally want to expand the definition and let more people benefit from the services. OHRHA would remove this incentive and allow a more reasoned political dialogue about who is homeless. It would focus that dialogue around the harms of homelessness. But whatever definition was used, OHRHA would discourage that condition.

Of course, OHRHA does not imply that homeless people should be treated poorly. What I have said so far about OHRHA does not depend on how homeless people are treated. Optimal policies for homeless people depend in part on what homelessness prevention activities are in place. This is a difficult topic that is not the subject of this paper. But intuitively, it's safe to say OHRHA will make the shelter conditions that are optimal better than the shelter conditions that would be optimal in the absence of a homelessness prevention program. Without OHRHA, too many people become homeless and any improvement in shelter conditions draws even more people who should not be into shelters. Improvements to shelter conditions without OHRHA are more socially expensive than improvements with OHRHA in place for two reasons because there are more people in shelters, and because the marginal person who will be drawn to a shelter from an improvement will be different from a person who would be in a shelter under optimal conditions. Another way of looking at this matter is that I introduced OHRHA as a substitute for punishing homeless people. Without OHRHA some of the reasons to punish homeless people remain in place and show up as a decrease in optimal shelter conditions. A more rigorous and detailed version of this argument is in O'Flaherty. ${ }^{16}$

\section{OTHER GOALS}

Many countries and several Canadian provinces have housing allowances. None of them look much like OHRHA. If this variety of housing allowance is the best for reducing homelessness, why does nobody use it? This is mainly because these other housing allowances were designed with other goals in mind. The virtual exclusion of non-elderly single adults from these programs is pretty good evidence that they were not intended to reduce homelessness. As far as I know, no jurisdiction has ever designed a housing subsidy solely to deal with homelessness.

Calgary might also be interested in pursuing other goals. In this section, I'll discuss two other possible goals that are complementary to reducing homelessness (or at least not contradictory). They are: (1) reducing instability and (2) promoting good health, employment and child development. I'll show how programs can be developed for these goals, and how they can be easily integrated with OHRHA.

\section{Reducing instability}

Many systems of housing assistance for poor people provide implicit insurance, most commonly through the rent-geared-to-income (RGI) feature. If a household has bad luck and its income goes down, the subsidy it gets goes up to partially offset its bad luck. This feature insures landlords, too. Tenant misfortunes are less likely to create costly vacancies or delinquencies for them. In Canada, social housing operates on an RGI basis and so do the provincial housing allowances.

\footnotetext{
16 O'Flaherty, (2011a).
} 
Insurance is thus valuable in itself to low-income households (and their landlords). Insurance has external benefits as well. Substantial evidence ${ }^{17}$ indicates that residential instability is bad for kids, and probably for their classmates, too. To the extent that insurance reduces residential moves, kids and their classmates benefit. Better-insured households may also be willing to invest more in socially beneficial goods like friendship with their neighbours because they have a better chance of staying with these neighbours for a long time.

Insurance can also reduce homelessness. Often, if not always, homelessness results from bad luck, and timely insurance payments can eliminate or at least postpone homeless spells. This is the basic idea behind homelessness prevention programs.

Theoretical models do not guarantee this result, since households may react to better insurance by reducing precautionary savings. But if OHRHA is in place, actuarially fair insurance makes households better off, and the value of their gain is greater than the government's loss, if any. ${ }^{18}$

Since insurance like this produces external benefits, private markets will underprovide it even when an optimal OHRHA is in place. A few small housing allowance programs have been designed with this goal in mind. For instance, in the 1980s Victoria province in Australia had a rental subsidy program designed to assist families in temporary crises. ${ }^{19}$ But a housing allowance program is not necessary for providing insurance, as homelessness prevention programs demonstrate.

The obvious way to promote housing stability is for the government to provide rental interruption insurance. Once established, rental interruption insurance might break even and be provided without subsidy by private companies, but I doubt it. One private company, Insurent, offers rental interruption insurance in New York City, but mainly at the higher end of the market.

Rental interruption insurance would work like mortgage insurance, but for renters (the first proposal, designed for veterans in the US, was modeled on Veterans' Administration mortgage insurance, which is widely used). When a tenant began a lease, she and the landlord would pay a premium and sign agreements with the insurance entity. The agreements would specify a set of well-defined events - for instance, involuntary job loss, serious medical problems and divorce - that would cause the insurance to kick in. If any of these events happened, and the tenant couldn't continue paying full rent, the insurance entity would step in and pay a fixed amount of rent for a fixed period of time (say, \$500 a month for up to six months), or until the tenant could get back on her feet, whichever came first. Partial payments, too, might be possible. To reduce moral hazard, the tenant would owe the insurance entity some proportion of the amount spent and would have to pay it back over time.

\footnotetext{
17 Phipps, S., (1999), "Economics and the well-being of Canadian children," Canadian Journal of Economics 32: 113563.

18 O’Flaherty (2011a).

19 Howenstine, E. Jay, (1986), p.16, Housing Vouchers: An International Analysis. New Brunswick, N.J.: Rutgers University.
} 
Because this program pays only in emergencies, and because some of its expenses are offset by premiums and clawbacks, it does not require a large subsidy per household (once the right parameters are discovered), and so could cover a large number of households without significant government expenditure. It would not prevent the most serious crises, but it would ameliorate many of the less serious ones and so bring households some peace of mind. It is not a substitute for more traditional parts of the safety net like unemployment insurance and a drug plan. But with insurance like this, kids would not have to move so often and homelessness would probably be reduced.

There should be indirect benefits as well. Some groups, like mentally ill people or former foster children, whom landlords might stereotype as poor tenants, would find doors opening more easily for them because landlords would be at least partially indemnified if the tenancy turned bad. Social service agencies would also have an early warning system. Landlords would be eager to report non-payment of rent when the households themselves might be reluctant or ashamed to ask for assistance. Problems that early intervention could solve would be less likely to fester and worsen.

Rental interruption insurance carries with it some risks of moral hazard, like all forms of insurance. Landlords will employ looser tenant selection procedures than they ordinarily would, but as I have pointed out, this could be socially desirable, since it may reduce stigma and provide easier access to housing for some people at risk of homelessness and for some people leaving homelessness. To the extent that screening activity by landlords is just a form of hot potato - trying to pass off bad luck to other landlords or shelters - it is socially worthless and SHOULD be reduced.

Tenant moral hazard is a more serious issue, since we don't want to encourage tenants to act irresponsibly. Designing programs to reduce moral hazard will be hard, but designers have at least two instruments: the definition of the triggering events and the ex post clawback provisions. Trial and error is probably the only way to get this right.

Rental interruption insurance can be implemented without an OHRHA in place, but it is also a good complement to an OHRHA. Like OHRHA, rental interruption insurance operates nowhere in the world, as far as I can tell, although there are several close analogues and the idea is under serious consideration in several US venues.

Probably the closest analogue is the rent bank program that operates in Toronto. ${ }^{20}$ Under this program, households with regular sources of income that are facing imminent eviction can borrow two months of rent. They must demonstrate the long-term sustainability of their situation and pay the loan back, but with no interest.

Since no premium is charged up front and no interest on the loan is collected, this program is guaranteed to lose money, which is a small difference with rental interruption insurance. Other agencies in Ontario run similar programs with fixed subsidies, and apparently they exhaust their subsidies and must turn eligible applicants away, ${ }^{21}$ that is a big difference with rental interruption insurance.

${ }^{20}$ City of Toronto, Shelter, Support, and Housing Administration, (2011), The Toronto Rent Bank. Accessed on August 15, 2011 at http://www.toronto.ca/housing/rentbank.htm

21 Province of Ontario, Ministry of Municipal Affairs and Housing, (2011), Provincial Rent Bank Program-Tenant FAQs. Accessed on August 15, 2011 at http://www.mah.gov.on.ca/Page1145.aspx 
The Toronto rent bank is one of the many forms rental interruption insurance could take. The other variants could allow smaller or larger subsidies or none at all, greater protection against moving children to new schools, wider eligibility to households with variable income, more protection against moral hazard, or less reliance on ex post clawbacks. Calgary could imitate Toronto directly, or explore some of these options.

\section{Promoting good health, employment, and child development}

Historically, concern about the external effects of poor housing has been a major impetus behind low-income housing programs. Slums, it was believed, bred disease, crime and moral degeneracy, and so getting rid of slum housing would help everyone in a city, not just the former slum-dwellers. In the 20th century US, this concern led to housing regulation, then public housing and then a housing voucher program that imposed detailed physical requirements on any structure it helped pay for. Canada never took the third step.

OHRHA does nothing about the conditions under which housed people are housed. If the only goal is to reduce homelessness, that's appropriate. Anything else would cost more or reduce homelessness less. But if Calgary has goals beyond non-homelessness, an additional housing allowance can be used to further those goals. I'll call it the supplemental housing allowance (SHA).

I don't see any reason why Calgary's approach on the SHA should be anything like the US approach - physical requirements on the structure that must be met or no subsidy is given. Both the emphasis on structure and the absolute nature of the rule are outdated.

The physical structure of almost all housing is much better than it was a century ago, or even a half-century ago, and cities have housing codes that address most of the major health externality issues connected with structure. The basic habitability standards are in provincial minimum housing and health standards, and they are supplemented by municipal fire safety and community standards by-laws. The codes apply to every housing unit, whether it's subsidized or not. So in general there seems to be no need to impose higher standards on subsidized housing than those that apply to all housing. (Whether these standards are too high, too low or just right is a question I can't comment on.) Lead paint in old buildings built before Canada banned most lead paint in 1976 is a possible exception, and I discuss it below.

Especially in a relatively new city like Calgary, where fewer than four percent of units were built before World War II, the main externality concerns about housing are about location, not structure. Scholarly and popular articles argue that poor people live in locations that are too far from good schools and good jobs, and too close to pollution, fast-food outlets and open-air drug sales. ${ }^{22}$

22 Grigsby, W.G. and S.C. Bourassa, (2004), "Section 8: The time for fundamental program change?" Housing Policy Debate 15 (4): 805-34. 
Even for people who live in unsubsidized housing, as most poor people and almost all nonpoor people in Calgary do, markets won't properly reflect all the costs and benefits of good health, good job access and good education. Many health costs are paid by the government, unemployment is subsidized through unemployment insurance and reduced taxes, and so is poor education; even without the fiscal transfers, a person rarely realizes all of the benefits she bestows on society by being a well-educated, discerning, inventive person. As a result, the amount in added housing cost that people are willing to pay for better health, better job access and better education is less than the true social benefit.

These are not the type of problems that are best dealt with through absolute rules. Harms and benefits are gradual functions of distance; there are no sharp cut-offs or discontinuities. Living 100 metres from a fast-food outlet is better for your children's health than living 75 metres away, but it's worse than 125 metres; subsidizing 100 metres fully and prohibiting 75 metres absolutely is not the best approach. ${ }^{23}$

Thus a housing allowance designed for modern externalities should vary payment based on the objective conditions of the housing unit; it should be another Pigouvian subsidy. Households living in housing in healthy locations with good job access and good schools should get a large subsidy; those in the opposite kind of location should get a much smaller one. See O'Flaherty for a much more detailed description of how this could be done in the U.S. context. ${ }^{24}$ The subsidy a household gets should depend only on its location, not on its rent or income.

One possible exception to the location-only formula is the presence or absence of lead paint. The Canadian ban on lead paint was not retroactive, and so lead paint may be present in some older Calgary homes. Exposure to lead is extremely deleterious, especially for children, and so subsidies for homes with lead paint should be lower than those for homes without.

The subsidy per person should not depend on household size, either. A household with twice as many adults should get twice the subsidy. The subsidy for children, of course, should be different from the subsidy for adults. Job access, for instance, should matter for the adult subsidy, and education for the child subsidy.

Notice that the logic of the SHA is just the same as the logic of the OHRHA; the two housing allowances fit together seamlessly. OHRHA is what you get for living in legal housing with the worst possible external effects; SHA is what you get for improving the external environment.

The combination of OHRHA and SHA is also the way to avoid feckless arguments about what the correct definition of homelessness is. It's the external costs of various housing conditions that matter, not what we call them. For me, it's convenient to call the conditions that are so bad you don't get a subsidy at all homelessness. If somebody wants to label other conditions conditions where you get a pretty small subsidy - as homelessness as well, that's fine with me too. I want to spend my energy on trying to measure the effects of housing and non-housing conditions, not on trying to name them.

\footnotetext{
23 Weitzman, Martin L., (1974), "Prices vs. quantities," Review of Economic Studies 41 (4): 477-91.

24 O'Flaherty, Brendan, (2011b), "Rental housing assistance for the 21st century," Cityscape 13(2): 127-46.
} 
I don't claim that SHA will reduce homelessness; it probably won't. Nor will it make poor people better off directly in the short run; rents in good neighbourhoods will probably be bid up, as they should be. But it should improve health, education and employment. It will do this by giving landlords incentives to get nuisances out of their neighbourhoods and lobby for better schools and transportation, and by encouraging vulnerable poor people to leave neighbourhoods that are irremediably noxious. If neighbourhoods around bad schools were mainly senior citizens and the schools were mainly empty, and the neighbourhoods around congested highways were mainly warehouses, the world would be a better place.

Some may think it perverse that larger subsidies go to people living under conditions that are probably better for them, as well as having more external benefits; it's not. What is perverse is paying people to live under conditions that are bad for them and everyone else. Some very poor people live under terrible conditions now, and under SHA and OHRHA the subsidy they get would be very small. But they get no subsidy now, and so they would not be worse off, and they would have a better opportunity to move to a healthier location.

\section{NOTE ON PUBLIC AND SOCIAL HOUSING}

So far I have said nothing about who owns the housing that subsidy recipients live in. That's because ownership didn't matter for the goals I was writing about. Arguments about ownership are about different goals. For instance, the arguments in the US for promoting ownership rather than tenancy are mainly about changing people's characters so that they are more sober, responsible and (often) conservative. Arguments for social housing are often about the quality of landlord-tenant relationships. My concern has been incentives, not ownership. These subsidies are compatible with many different arrangements of ownership.

\section{CONCLUSION}

I had planned to write a longer paper, but the ideas could not sustain it. Many questions like this require answers that are complex and difficult, but not this one.

The paper is also short because the answer is so far from current experience that it comes unencumbered by practical wisdom or empirical evidence. I have included an appendix of empirical results about existing and past housing allowances, but these programs are so different from OHRHA (and rental interruption insurance and SHA) that the results have only modest relevance.

I have provided ideas for innovative approaches to dealing with homelessness. The ideas are simple and straightforward. What's required now is careful consideration of issues such as the size of the OHRHA subsidy and the potential it may have for moving people away from the cusp of homelessness. Perhaps second-best approaches to financing OHRHA might also be studied - using general revenues, for instance, and reducing the size of some other housing programs. Maybe in a few years someone will have the material to write a long paper about OHRHA and report on these findings. I would love to read it. 


\section{APPENDIX: EMPIRICAL STUDIES OF HOMELESSNESS AND HOUSING ALLOWANCES}

\section{Welfare-to-Work Vouchers}

The most relevant results on the relationship between housing allowances and homelessness come from the Welfare-to-Work Voucher (WtWV) program, a large-scale experiment conducted in the US between 2000 and 2004. The bottom line is that the vouchers used in this controlled experiment substantially reduced homelessness among recipients, but the reduction in PIT homelessness per 100 vouchers was modest.

In this experiment, several thousand welfare (Temporary Assistance to Needy Families) families were randomly assigned to treatment and control groups. Treatment group families received a standard Section 8 voucher and control group families did not (although a few control group families received vouchers through normal processes as the experiment went on). See Mills for a complete description and results. ${ }^{25}$

The chief finding on homelessness was that families with vouchers were substantially less likely to become homeless than control families. Note that I am using "homeless" throughout this appendix to mean living on the streets or in shelters; that is how most empirical studies use the term. The effect of treatment on the treated (TOT) was to reduce the (regression-adjusted) probability of experiencing a spell of homelessness in the year before the follow-up interview by 9.2 percent (exhibit 5.3).

Ellen and O'Flaherty translate this TOT effect into a reduction in PIT homelessness using ratios from U.S. national data. ${ }^{26}$ Their estimate is that PIT homelessness among families would go down by 3.5 for every hundred vouchers. Section 8 vouchers appear to be effective in reducing homelessness among families who receive them, but many families have to receive them to make much of a dent in homelessness.

The WtWV results, while the strongest and most relevant we have, cannot address two important questions about the impact of Section 8 on homelessness (and of course do not say a lot about housing allowance programs unlike Section 8). The first question is whether the effect on single adults is the same as the effect on families with children. The second question is how such programs affect non-recipients - whether, for instance, they raise rents for nonrecipients and drive some non-recipients into homelessness.

\section{Single adults}

On the first question, virtually nothing is known. This is a serious shortcoming, since the majority of homeless people are non-elderly single adults.

\footnotetext{
25 Mills, Gregory et al., (2006), Effects of Housing Vouchers on Welfare Families, Washington: U.S. Department of Housing and Urban Development, Office of Policy Development and Research.

${ }^{26}$ Ellen, Ingrid Gould and Brendan O'Flaherty, (2007), p.12, footnote 3, "Do government programs make households too small? Evidence from New York City,” Population Research and Policy Review 26 (4): 387-409.
} 
Very little is known because very few such adults receive Section 8 vouchers. Early shows that the virtual exclusion of single non-elderly adults from all US mainstream housing programs is an important reason why the demographic characteristics of homeless households are very different from those of households receiving housing assistance (not just Section 8). ${ }^{27}$ But his implication for the reduction in homelessness for 100 additional subsidized households is not much different from the WtWV estimate: between 3.8 and 5.0.

No one knows for sure why single adults get so little help, since in the US they are eligible for it. Khadduri argues that information networks are responsible. ${ }^{28}$ Any housing allowance designed to reduce homelessness would have to include large numbers of single non-elderly adults, and the experience with such housing allowances is meager.

Some weak evidence that housing allowances might reduce homelessness among single nonelderly adults, however, can be found in Dasinger and Speiglman. ${ }^{29}$ This paper looks at a group of people with AIDS or HIV, 77 percent of whom lived alone. They received shallow rent subsidies, the amount of which depended only on household size and number of bedrooms. Their housing status was tracked over several years and compared with that of an administratively constructed comparison group. The subsidies were considerably simpler and smaller than Section 8 subsidies. Holding many variables constant, program participants were significantly less likely to transition out of independent living.

For our purposes, this study has two major weaknesses. First, homelessness is only one way of several to transition out of independent living (for instance, doubling up is another), and the paper does not report on transitions to homelessness. Second, the administratively constructed comparison group differed in observable ways from the treatment group, and may have differed in unobservable ways.

\section{Non-recipients}

Some work that touches on the question of non-recipients has been done. Early and Olsen is the most important paper. ${ }^{30}$ They look at a cross-section of metropolitan areas and regress PIT homelessness on the availability of housing subsidies, the extent to which subsidies are targeted to extremely poor people, and a variety of control variables. Because they look at total homelessness rather than homelessness among subsidized households, they can estimate the total effect of subsidies: the sum of the effects on recipients and on non-recipients. They find that the number of subsidies has no effect on homelessness, but that better income targeting reduces homelessness. Shifting 100 subsidies from richer households to poorer households reduces PIT homelessness by 7.7. This suggests that while subsidies may harm non-recipients, targeting reduces net harm.

27 Early, Dirk W., (1998), "The role of subsidized housing in reducing homelessness: An empirical investigation using micro-data," Journal of Policy Analysis and Management 17 (4): 687-96; - (2004), "The determinants of homelessness and the targeting of housing assistance," Journal of Urban Economics 55: 195-214.

28 Khadduri, Jill, (2010), "Rental subsidies: Reducing homelessness," pp. 59-88 in Ingrid Ellen and Brendan O'Flaherty, eds., How to House the Homeless. New York: Russell Sage.

29

Dasinger, Lisa K. and Richard Speiglman, (2007), "Homeless prevention: The effect of a shallow rent subsidy on housing outcomes among people with HIV or AIDS," AIDS and Behaviour 11 (supplement): S128-S139.

30 Early, Dirk W., and Edgar O. Olsen, (2002), "Subsidized housing, emergency shelters, and homelessness: An empirical investigation using data from the 1990 census," Advances in Economic Analysis, 2, n.p. 
The paper's main weakness for our purposes is that Section 8 subsidies are not the majority of the subsidies studied; supply-side subsidies are included as well. Also the paper does not test for endogeneity of subsidies.

Mansur et al. is the other paper that addresses this issue, but it is a simulation, not original empirical work. ${ }^{31}$ They simulate the effect of various housing allowance schemes on homelessness and rents in California's four metropolitan areas and find that a universal housing allowance for poor renters causes major reductions in homelessness everywhere, without large rent increases. This housing allowance is considerably less generous than Section 8. In the simplest case (San Francisco), PIT homelessness is reduced by 2.2 for every 100 subsidies.

The parameters used in this simulation, although empirically grounded, are never perfect. The most serious problem with this paper in my mind is that it ignores the effect of housing allowances on household size. Section 8 vouchers are worth more per person to small households than to large; they reduce household size and so raise housing demand..$^{32,33,34}$ Steele found no evidence of reduced sharing among 55-64 year old households in Canadian provinces as a result of housing allowances, but this is not the group that would be expected to respond strongly to these incentives. ${ }^{35}$ While Section 8 vouchers are not neutral with respect to household size, OHRHA should be. The imaginary program that Mansur et al. simulated may be closer to OHRHA than to Section 8.

Notice that in all these empirical studies, the reduction in PIT homelessness per 100 subsidies is well below 10. Although it's possible that some programs might do better than this, it is probably foolhardy to assume that any unknown program would do better. Better targeting is often purchased at the expense of more moral hazard.

31 Mansur, Erin, John Quigley, Steven Raphael, and Eugene Smolensky, (2002), "Examining policies to reduce homelessness using a general equilibrium model of the housing market," Journal of Urban Economics 52: 316-40.

32 Mills et al., (2006).

33 Ellen and O'Flaherty, (2007).

34 Sinai, Todd and Joel Waldfogel, (2005), "Do low-income housing subsidies increase the occupied housing stock?" Journal of Public Economics 89 (11-12): 2137-64.

35 Steele, Marion, (1985), “Canadian Housing Allowances: An Economic Analysis," Ontario Economic Council Research Study 33. Toronto: Ontario Economic Council, University of Toronto Press. 


\section{About the Authors}

Brendan O'Flaherty is a professor of economics at Columbia University. Most of his work is in urban economics; in particular, homelessness, crime, housing, and race. He has published books on homelessness and on urban economics, and is currently working on a book about the economics of race. Professor O'Flaherty has been involved in the civic and political life of Newark, New Jersey since 1954, from both inside and outside of government. 


\section{ABOUT THIS PUBLICATION}

The School of Public Policy Research Papers provide in-depth, evidence-based assessments and recommendations on a range of public policy issues. Research Papers are put through a stringent peer review process prior to being made available to academics, policy makers, the media and the public at large. Views expressed in The School of Public Policy Research Papers are the opinions of the author(s) and do not necessarily represent the view of The School of Public Policy.

\section{OUR MANDATE}

The University of Calgary is home to scholars in 16 faculties (offering more than 80 academic programs) and 36 Research Institutes and Centres including The School of Public Policy. Under the direction of Jack Mintz, Palmer Chair in Public Policy, and supported by more than 100 academics and researchers, the work of The School of Public Policy and its students contributes to a more meaningful and informed public debate on fiscal, social, energy, environmental and international issues to improve Canada's and Alberta's economic and social performance.

The School of Public Policy achieves its objectives through fostering ongoing partnerships with federal, provincial, state and municipal governments, industry associations, NGOs, and leading academic institutions internationally. Foreign Investment Advisory Committee of the World Bank, International Monetary Fund, Finance Canada, Department of Foreign Affairs and International Trade Canada, and Government of Alberta, are just some of the partners already engaged with the School's activities.

For those in government, The School of Public Policy helps to build capacity and assists in the training of public servants through degree and non-degree programs that are critical for an effective public service in Canada. For those outside of the public sector, its programs enhance the effectiveness of public policy, providing a better understanding of the objectives and limitations faced by governments in the application of legislation.

\section{DISTRIBUTION}

Our publications are available online at www.policyschool.ca.

\section{DISCLAIMER}

The opinions expressed in these publications are the authors' alone and therefore do not necessarily reflect the opinions of the supporters, staff, or boards of The School of Public Policy.

\section{COPYRIGHT}

Copyright (C) 2012 by The School of Public Policy.

All rights reserved. No part of this publication may be reproduced in any manner whatsoever without written permission except in the case of brief passages quoted in critical articles and reviews.

\section{ISSN}

1919-112x SPP Research Papers (Print)

1919-1138 SPP Research Papers (Online)

\section{DATE OF ISSUE}

January 2012

\section{MEDIA INQUIRIES AND INFORMATION}

For media inquiries, please contact Morten Paulsen at 403-453-0062.

Our web site, www.policyschool.ca, contains more information about The School's events, publications, and staff.

\section{DEVELOPMENT}

For information about contributing to The School of Public Policy, please contact Candice Naylen by telephone at 403-210-7099 or by e-mail at cnaylen@ucalgary.ca.

\section{EDITOR}

Timothy Giannuzzi 


\section{RECENT PUBLICATIONS BY THE SCHOOL OF PUBLIC POLICY}

PUBLIC SECTOR WAGE GROWTH IN ALBERTA

http:// policyschool.ucalgary.ca/sites/default/files/research/boessenkool-public-wage.pdf Ken Boessenkool and Ben Eisen | January 2012

CATCHING THE BRASS RING: OIL MARKET DIVERSIFICATION POTENTIAL FOR CANADA http:// policyschool.ucalgary.ca/ sites/default/files/research/mmoore-oilmarket.pdf M.C. Moore, S. Flaim, D. Hackett, S. Grissom, D. Crisan and A. Honarvar | December 2011

THE CONSTITUTIONALITY OF FEDERAL CLIMATE CHANGE LEGISLATION

http:/ / policyschool.ucalgary.ca/?q=content/ constitutionality-federal-climate-change-legislation Alastair Lucas and Jenette Yearsley | December 2011

THE MYTHS AND FACTS OF FOSSIL FUEL SUBSIDIES: A CRITIQUE OF EXISTING STUDIES http:/ / policyschool.ucalgary.ca/files/publicpolicy/MCKENZIE\%20MINTZ\%20online.pdf Kenneth J. McKenzie and Jack M. Mintz | October 2011

HOMELESSNESS IN ALBERTA: THE DEMAND FOR SPACES IN ALBERTA'S HOMELESS SHELTERS http:// policyschool.ucalgary.ca/files/public policy/homelessness\%20in\%20alberta.pdf Ronald Kneebone, J.C. Herbert Emery and Oksana Grynishak | September 2011

THE NEW SECURITY PERIMETER WITH THE UNITED STATES

http:// policyschool.ucalgary.ca/files/ publicpolicy/flemming\%20sept011.pdf Brian Flemming | September 2011

INCOME SUPPORT FOR PERSONS WITH DISABILITIES

http:// policyschool.ucalgary.ca/files/publicpolicy/Kneebone_Disability_Study.pdf

Ronald Kneebone and Oksana Grynishak | September 2011

INVESTMENT REVIEW IN CANADA - WE CAN DO BETTER

http:// policyschool.ucalgary.ca/files/publicpolicy/Herman\%20Invest\%20Canada\%20online.pdf Lawrence L. Herman | September 2011

PLUCKING THE GOLDEN GOOSE: HIGHER ROYALTY RATES ON THE OIL SANDS GENERATE SIGNIFICANT INCREASES IN GOVERNMENT REVENUE

http:/ / policyschool.ucalgary.ca/files/publicpolicy/KMckenzie\%20comm\%20sept11.pdf

Kenneth J. McKenzie | September 2011

ENVIRONMENTAL BENEFITS OF USING WIND GENERATION TO POWER PLUG-IN HYBRID ELECTRIC VEHICLES http:/ / policyschool.ucalgary.ca/files/ publicpolicy/enviro\%20hybrid\%20wind\%20energy.pdf

Mahdi Hajian, Monishaa Manickavasagam, William D. Rosehart and Hamidreza Zareipour | August 2011

A FRESH START ON IMPROVING ECONOMIC COMPETITIVENESS AND PERIMETER SECURITY

http:/ / policyschool.ucalgary.ca/files/ publicpolicy/dburney.pdf

Derek H. Burney | August 2011

PIIGS “Я” US?

http:// policyschool.ucalgary.ca/files/ publicpolicy/US\%20debt\%20crisis.pdf

Stephen R. Richardson | July 2011

RHETORIC AND REALITIES: WHAT INDEPENDENCE OF THE BAR REQUIRES OF LAWYER REGULATION http:/ / policyschool.ucalgary.ca/files/publicpolicy/A_Woolley_lawregulat_c.pdf

Alice Woolley | June 2011 